
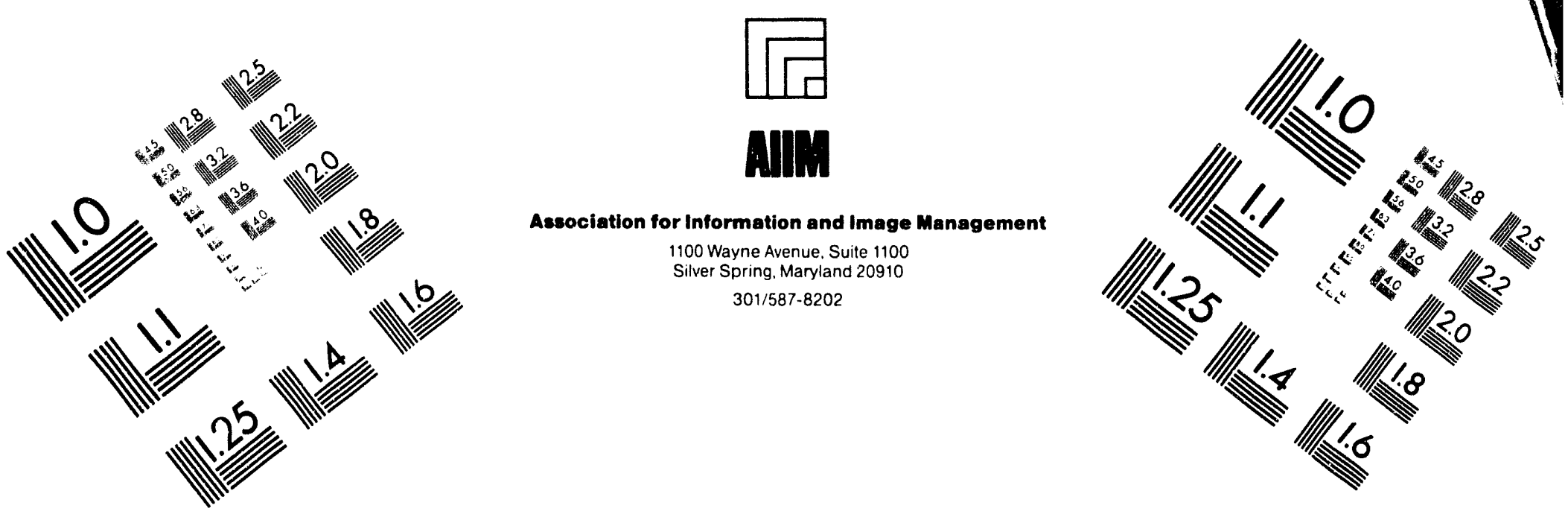

\title{
Centimeter
}

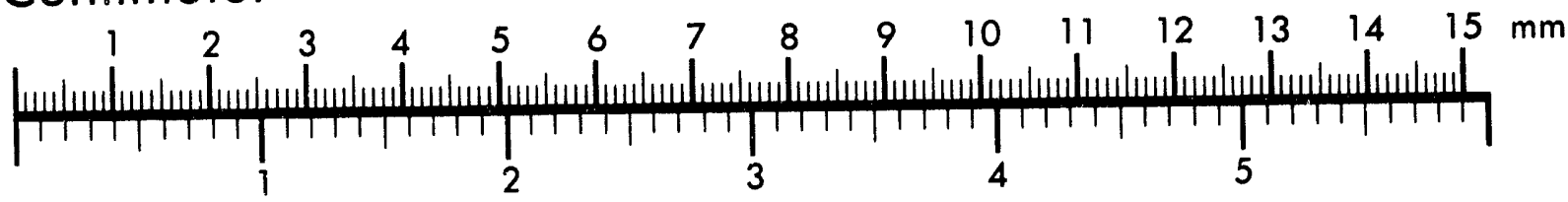
Inches

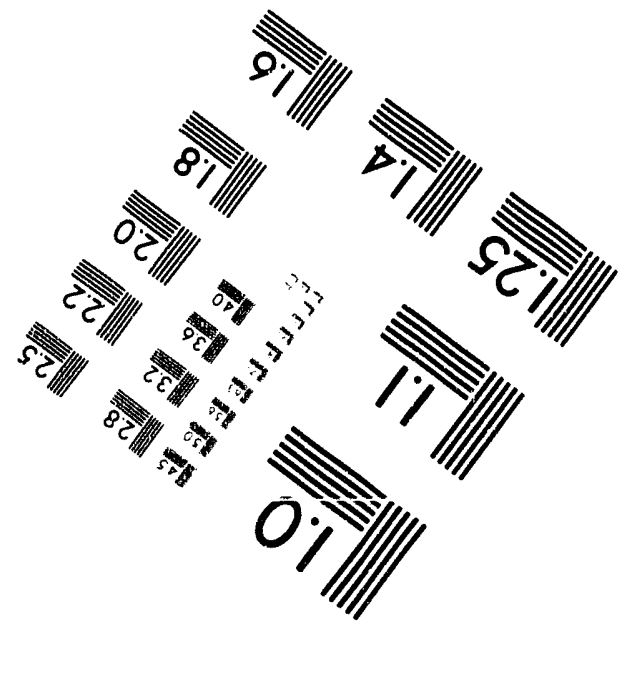

MANUFACTURED TO AIIM STANDARDS

BY APPLIED IMAGE, INC.

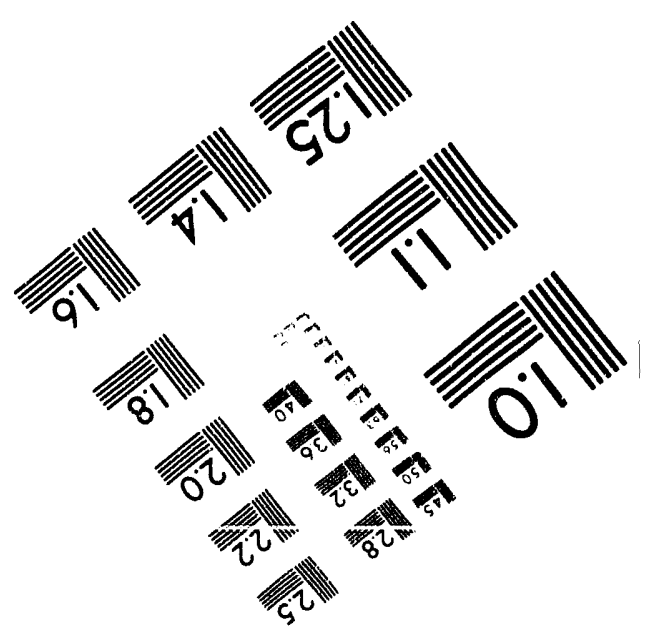



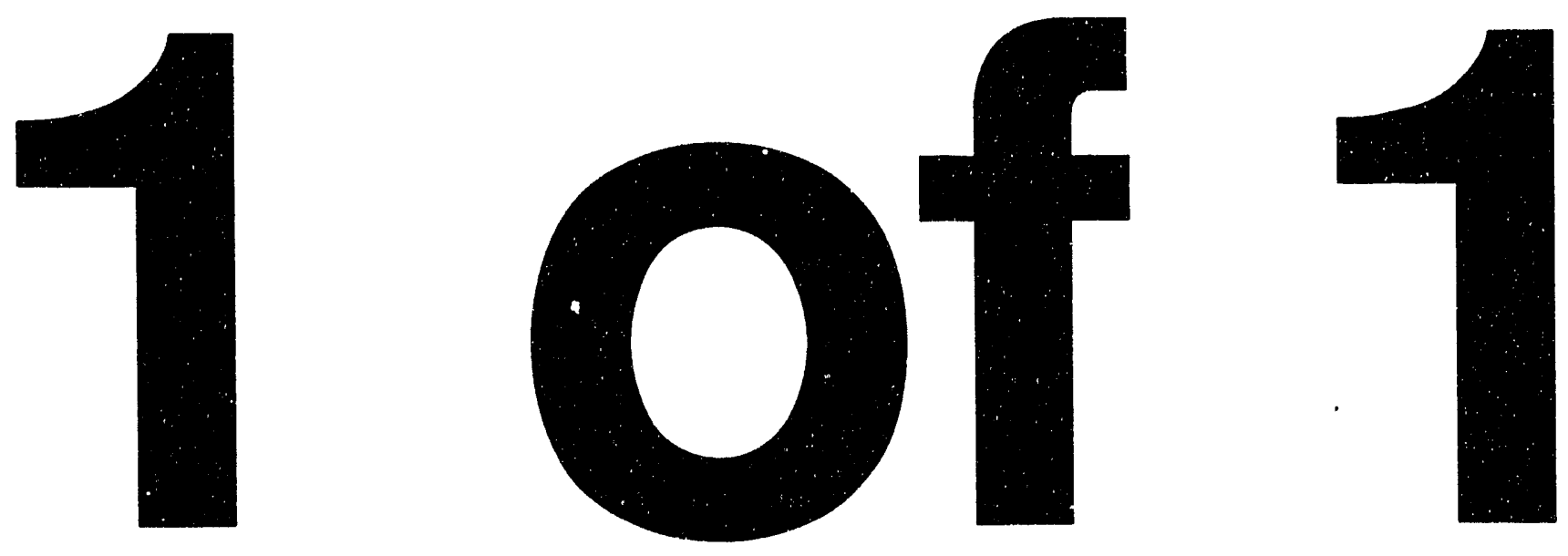
ORNL/RASA-93/3

\title{
HEALTH AND SAFETY RESEARCH DIVISION
}

Environmental Restoration and Waste Management Non-Defense Programs

(Activity No. EX 202001 0; ADS1310)

\section{RESULTS OF THE RADIOLOGICAL SURVEY AT 77 SINNINGER STREET, MAYWOOD, NEW JERSEY (MJ052)}

\author{
R. D. Foley and K. S. Brown
}

Date Published - June 1993

\section{Investigation Team}

R. D. Foley - Measurement Applications and Development Manager

W. D. Cottrell - Project Director

R. D. Foley - Field Survey Supervisor

\author{
Survey Team Members \\ D. E. Rice \\ W. H. Shinpaugh ${ }^{1}$
}

${ }^{1}$ D. R. Stone and Associates, Inc.

Work performed by the

MEASUREMENT APPLICATIONS AND DEVELOPMENT GROUP

Prepared by the

OAK RIDGE NATIONAL LABORATORY

Oak Ridge, Tennessee 37831-6285

managed by

MARTIN MARIETTA ENERGY SYSTEMS, INC.

for the

U. S. DEPARTMENT OF ENERGY

under contract DE-AC05-84OR21400 


\section{CONTENTS}

LIST OF FIGURES $\ldots \ldots \ldots \ldots \ldots \ldots \ldots \ldots \ldots \ldots \ldots \ldots \ldots \ldots \ldots$

LIST OF TABLES $\ldots \ldots \ldots \ldots \ldots \ldots \ldots \ldots \ldots \ldots \ldots \ldots \ldots \ldots \ldots \ldots \ldots \ldots \ldots$

ACKNOWLEDGMENTS $\ldots \ldots \ldots \ldots \ldots \ldots \ldots \ldots \ldots \ldots \ldots \ldots \ldots$

ABSTRACT $\ldots \ldots \ldots \ldots \ldots \ldots \ldots \ldots \ldots \ldots \ldots \ldots \ldots \ldots \ldots \ldots \ldots \ldots$

INTRODUCTION $\ldots \ldots \ldots \ldots \ldots \ldots \ldots \ldots \ldots \ldots \ldots \ldots \ldots \ldots \ldots$

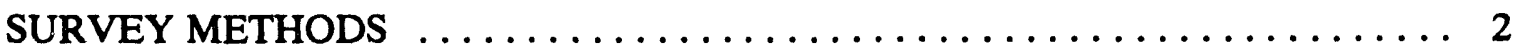

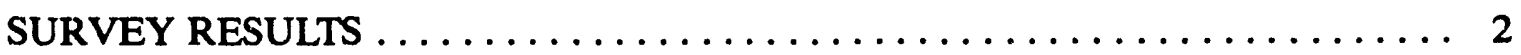

Surface Gamma Radiation Levels $\ldots \ldots \ldots \ldots \ldots \ldots \ldots \ldots \ldots \ldots$

Systematic Soil Samples $\ldots \ldots \ldots \ldots \ldots \ldots \ldots \ldots \ldots \ldots \ldots \ldots \ldots$

SIGNIFICANCE OF FINDINGS $\ldots \ldots \ldots \ldots \ldots \ldots \ldots \ldots \ldots \ldots \ldots \ldots \ldots$

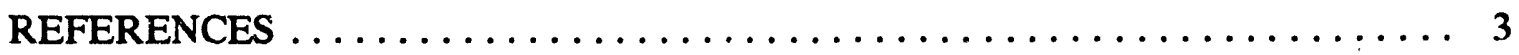

\section{DISCLAIMER}

This report was prepared as an account of work sponsored by an agency of the United States Government. Neither the United States Government nor any agency thereof, nor any of their employees, makes any warranty, express or implied, or assumes any legal liability or responsibility for the accuracy, completeness, or usefulness of any information, apparatus, product, or process disclosed, or represents that its use would not infringe privately owned rights. Reference herein to any specific commercial product, process, or service by trade name, trademark, manufacturer, or otherwise does not necessarily constitute or imply its endorsement, recommendation, or favoring by the United States Government or any agency thereof. The views and opinions of authors expressed herein do not necessarily state or reflect those of the United States Government or any agency thereof. 


\section{LIST OF FIGURES}

1 View looking northeast at 77 Sinninger Street, Maywood, New Jersey (MJ052) . . 4

2 View looking southwest at 77 Sinninger Street, Maywood, New Jersey (MJ052) . . 4

3 Surface gamma radiation levels $(\mu \mathrm{R} / \mathrm{h})$ and soil sampling locations at 77

Sinninger Street, Maywood, New Jersey (MJ052) . . . . . . . . . . . 5 


\section{LIST OF TABLES}

1 DOE guidelines for protection against radiation $\ldots \ldots \ldots \ldots \ldots \ldots \ldots$

2 Background radiation levels for the northern New Jersey area $\ldots \ldots \ldots \ldots \ldots$

3 Concentrations of radionuclides in soil at 77 Sinninger Street, Maywood, New Jersey $\ldots \ldots \ldots \ldots \ldots \ldots \ldots \ldots \ldots \ldots \ldots \ldots \ldots \ldots \ldots \ldots \ldots \ldots$ 


\section{ACKNOWLEDGMENTS}

This project was sponsored by the Office of Environmental Restoration, U.S. Department of Energy, under contract DE-AC05-84OR21400 with Martin Marietta Energy Systems, Inc. The authors wish to acknowledge the contributions of W. D. Cottrell, V. P. Patania, and D. A Roberts of the Measurement Applications and Development Group, Oak Ridge National Laboratory, for participation in the analyses, editing, and reporting of data for this survey. The authors also wish to thank J. F. Allred and D. A. Rose for sample preparation and T. R. Stewart for computer graphics. 


\begin{abstract}
Maywood Chemical Works (MCW) of Maywood, New Jersey, generated process wastes and residues associated with the production and refining of thorium and thorium compounds from monazite ores from 1916 to 1956 . MCW supplied rare earth metals and thorium compounds to the Atomic Energy Commission and various other government agencies from the late 1940 s to the mid-1950s. Area residents used the sandlike waste from this thorium extraction process mixed with tea and cocoa leaves as mulch in their yards. Some of these contaminated wastes were also eroded from the site into Lodi Brook. At the request of the U.S. Department of Energy (DOE), a group from Oak Ridge National Laboratory conducts investigative radiological surveys of properties in the vicinity of $\mathrm{MCW}$ to determine whether a property is contaminated with radioactive residues, principally ${ }^{232} \mathrm{Th}$, derived from the $\mathrm{MCW}$ site. The survey typically includes direct measurement of gamma radiation levels and soil sampling for radionuclide analyses. The survey of this site, 77 Sinninger Street, Maywood, New Jersey (MJ052), was conducted on December 17, 1992.

Results of the survey demonstrated no radionuclide concentrations in excess of the DOE Formerly Utilized Sites Remedial Action Program criteria. The radionuclide distributions were not significantly different from normal background levels in the northern New Jersey area.
\end{abstract}




\section{RESULTS OF THE RADIOLOGICAL SURVEY AT 77 SINNINGER STREET, MAYWOOD, NEW JERSEY (MJ052)*}

\section{INTRODUCTION}

From 1916 to 1956, process wastes and residues associated with the production and refining of thorium and thorium compounds from monazite ores were generated by the Maywood Chemical Works (MCW), Maywood, New Jersey. During the latter part of this period, MCW supplied rare earth metals and thorium compounds to various government agencies. In the 1940 s and 1950 s, MCW produced thorium and lithium, under contract, for the Atomic Energy Commission (AEC). These activities ceased in 1956, and, approximately three years later, the 30-acre real estate was purchased by the Stepan Company. The property is located at 100 Hunter Avenue in a highly developed area in Maywood and Rochelle Park, Bergen County, New Jersey.

During the early years of operation, MCW stored wastes and residues in low-lying areas west of the processing facilities. In the early 1930 s, these areas were separated from the rest of the property by the construction of New Jersey State Highway 17. The Stepan property, the interim storage facility, and several vicinity properties have been designated for remedial action by the Department of Energy (DOE).

The waste produced by the thorium extraction process was a sandlike material containing residual amounts of thorium and its decay products, with smaller quantities of uranium and its decay products. During the years 1928 and 1944 to 1946, area residents used these process wastes mixed with tea and cocoa leaves as mulch in their lawns and gardens. In addition, some of the contaminated wastes were apparently eroded from the site into Lodi Brook and carried downstream.

Lodi Brook is a small stream flowing south from Maywood with its headwaters near the Stepan waste storage site. Approximately $150 \mathrm{ft}$ after passing under State Route 17, the stream has been diverted underground through concrete or steel culverts until it merges with the Saddle River in Lodi, New Jersey. Only a small section near Interstate 80 remains uncovered. From the 1940 s to the 1970 s when the stream was being diverted underground, its course was altered several times. Some of these changes resulted in the movement of contaminated soil to the surface of a few properties, where it is still in evidence. In other instances, the contaminated soil was covered over or mixed with clean fill, leaving no immediate evidence on the surface. Therefore, properties in question may be drilled in search of former streambed material, even in the absence of surface contamination.

As a result of the Energy and Water Appropriations Act of Fiscal Year 1984, the property discussed in this report and properties in its vicinity contaminated with residues from

\footnotetext{
* The survey was performed by members of the Measurement Applications and Development Group of the Health and Safety Research Division at Oak Ridge National Laboratory under DOE contract DE-AC05$840 R 21400$.
} 
the former $\mathrm{MCW}$ were included as a decontamination research and development project under the DOE Formerly Utilized Sites Remedial Action Program. As part of this project, $D O E$ is conducting radiological surveys in the vicinity of the site to identify properties contaminated with residues derived from the MCW. The principal radionuclide of concern is thorium-232. The radiological survey discussed in this report is part of that effort and was conducted, at the request of DOE and the property owner, by members of the Measurement Applications and Development Group of the Oak Ridge National Laboratory.

A radiological survey of the private, residential property at 77 Sinninger Street, Maywood, New Jersey, was conducted on December 17, 1992 and is summarized in this report.

\section{SURVEY METHODS}

The radiological survey of the property included: (1) a gamma scan of the entire property surface outdoors at the surface, and (2) collection of surface and subsurface soil samples. No indoor survey measurements were performed. The survey methods followed the basic plan outlined in a correspondence from W. D. Cottrell to A. J. Whitman. ${ }^{1}$ A comprehensive description of the survey methods and instrumentation has been presented in another report. ${ }^{2}$

Using a portable gamma scintillation meter, ranges of gamma exposure rates were recorded for areas of the property surface. Systematic soil samples were then obtained at randomly selected locations irrespective of the gamma exposure rates. Measurements were usually made and soil samples collected from depths of 0 to $30 \mathrm{~cm}$. The samples were analyzed for ${ }^{226} \mathrm{Ra},{ }^{232} \mathrm{Th}$, and ${ }^{238} \mathrm{U}$ content.

\section{SURVEY RESULTS}

Applicable DOE guidelines are summarized in Table $1 .^{3}$ The normal background radiation levels for the northern New Jersey area are presented in Table 2.,5 These data are provided for comparison with survey results presented in this report. All direct measurement results presented in this report are gross readings; background radiation levels have not been subtracted. Similarly, background concentrations have not been subtracted from radionuclide concentrations measured in soil samples.

Current photographs of the site are shown in Figs. 1 and 2.

\section{Surface Gamma Radiation Levels}

Gamma radiation levels measured during a gamma scan of the property surface are given in Fig. 3. Gamma exposure rates over the major portion of the property ranged from 4 to $9 \mu \mathrm{R} / \mathrm{h}$. The highest gamma levels at the surface ranged from $7-11 \mu \mathrm{R} / \mathrm{h}$ near the foundation of the house. This slight-elevation in gamma levels is typical of the naturally occurring radioactive substances present in bricks, concrete, granite, and other such materials used in paving and building construction. Otherwise, none of the measurements were elevated. 


\section{Systematic Soil Samples}

Systematic soil samples were taken from various locations on the property for radionuclide analyses. Locations of the systematic samples (S) are shown in Fig. 3, with results of laboratory analyses provided in Table 3. Concentrations of ${ }^{226} \mathrm{Ra},{ }^{232} \mathrm{Th}$, and ${ }^{238} \mathrm{U}$ in these samples ranged from 0.72 to $0.94 \mathrm{pCi} / \mathrm{g}, 0.88$ to $1.04 \mathrm{pCi} / \mathrm{g}$, and 1.1 to $2.3 \mathrm{pCi} / \mathrm{g}$, respectively. All samples were below DOE criteria (Table 1), and near or below the normal background level for ${ }^{238} \mathrm{U}$ for the northern New Jersey area (Table 2).

\section{SIGNIFICANCE OF FINDINGS}

Measurements and results of soil sample analyses taken at 77 Sinninger Street indicate that the property contains no significant radioactive contamination above normal background levels for this area. The slight elevation in the gamma level near the foundation is typical of the naturally occurring radioactive substances present in bricks, granite, concrete cinder blocks and other such materials used in paving and building construction. Assessments of soil samples and direct measurements at the site demonstrate no radiological contamination in excess of DOE guidelines.

\section{REFERENCES}

1. W. D. Cottrell, ORNL, to A. J. Whitman, DOE/HQ, correspondence, "Radiological Survey of Private Properties in Lodi, New Jersey" (August 15, 1984).

2. T. E. Myrick, B. A. Berven, W. D. Cottrell, W. A. Goldsmith, and F. F. Haywood, Procedures Manual for the ORNL Radiological Survey Activities (RASA) Program, Oak Ridge National Laboratory, ORNL/TM-8600 (April 1987).

3. U.S. Department of Energy, Guidelines for Residual Radioactive Material at Formèrly Utilized Sites Remedial Action Program and Remote Surplus Facilities Management Program Sites (Rev. 2, March 1987).

4. U.S. Department of Energy, Radiological Survey of the Middlesex Municipal Landfill, Middlesex, New Jersey, DOE/EV-00005/20 (April 1980).

5. T. E. Myrick, B. A. Berven, and F. F. Haywood, State Background Radiation Levels: Results of Measurements Taken During 1975-1979, Oak Ridge National Laboratory, ORNL/TM-7343 (November 1981). 


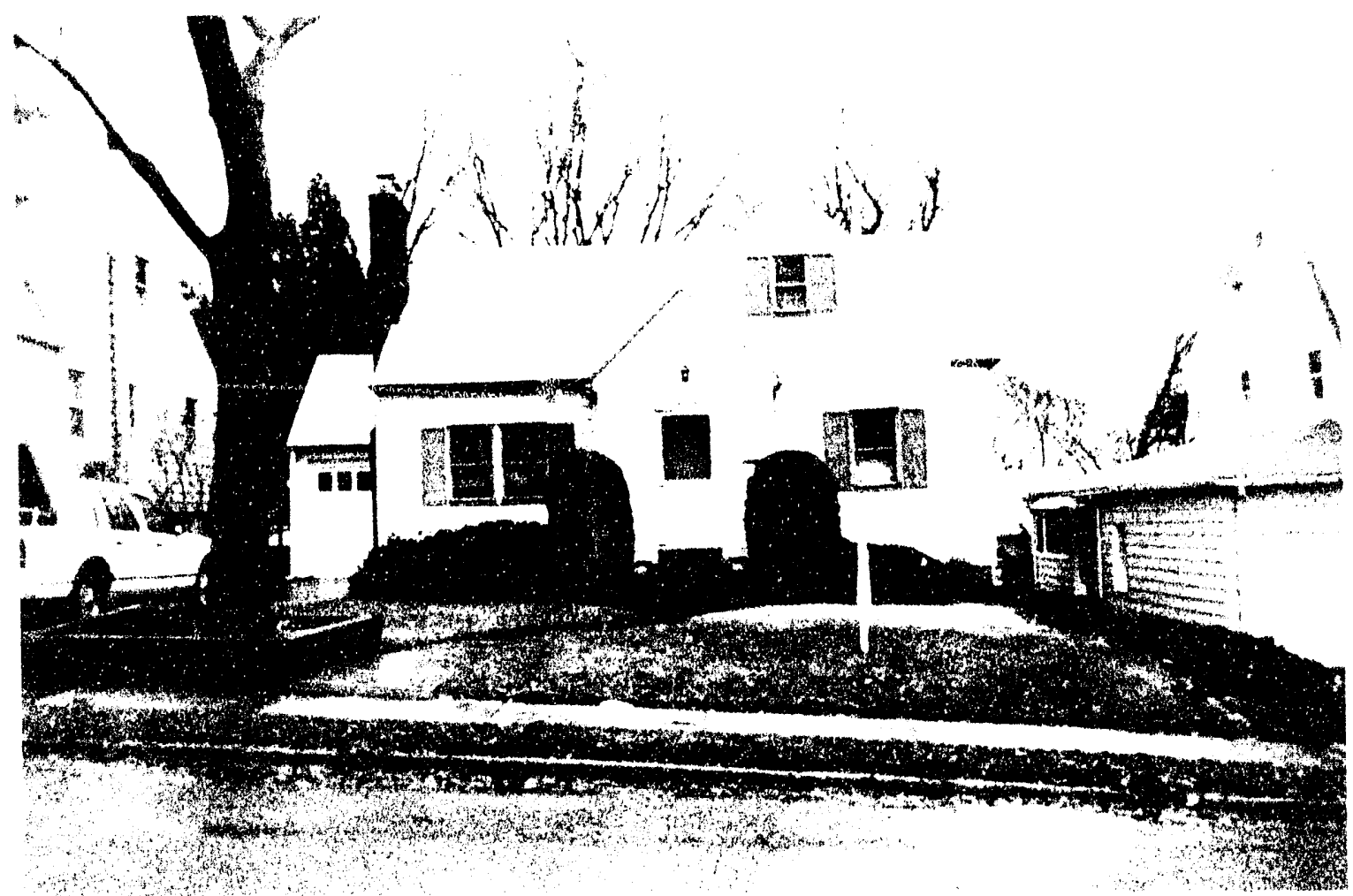

Fig. 1. View looking northeast at 77 Sinninger Street, Maywood, New Jersey (MJ052).

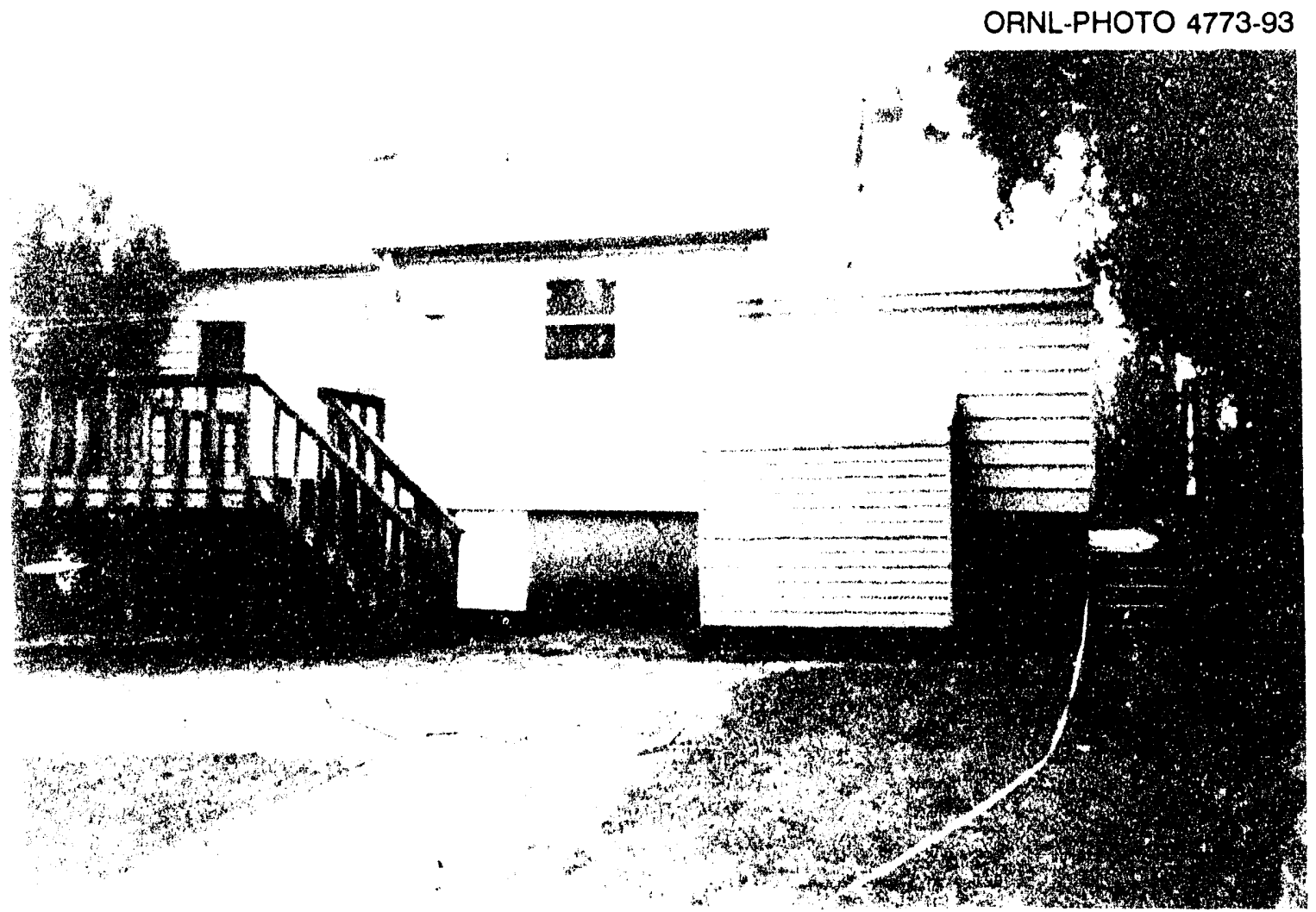

Fig. 2. View looking southwest at 77 Sinninger Street, Maywood, New Jersey (MíJ052). 


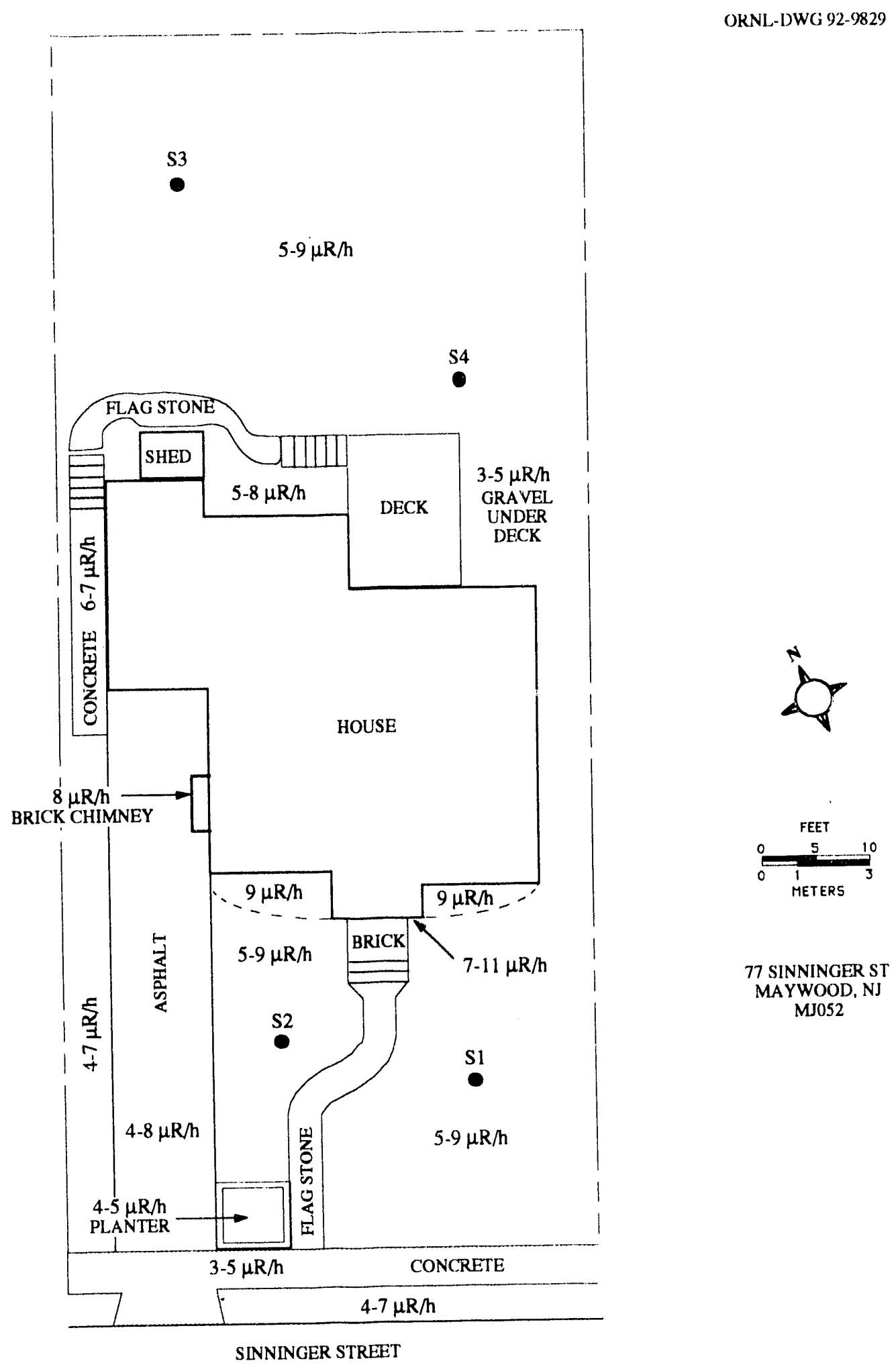

Fig. 3. Surface gamma radiation levels $(\mu \mathrm{R} / \mathrm{h})$ and soil sampling locations at 77 Sinninger Street, Mayood, New Jersey (MJ052). 
Table 1. Applicable guidelines for protection against radiation (Limits fo: uncontrolled areas)

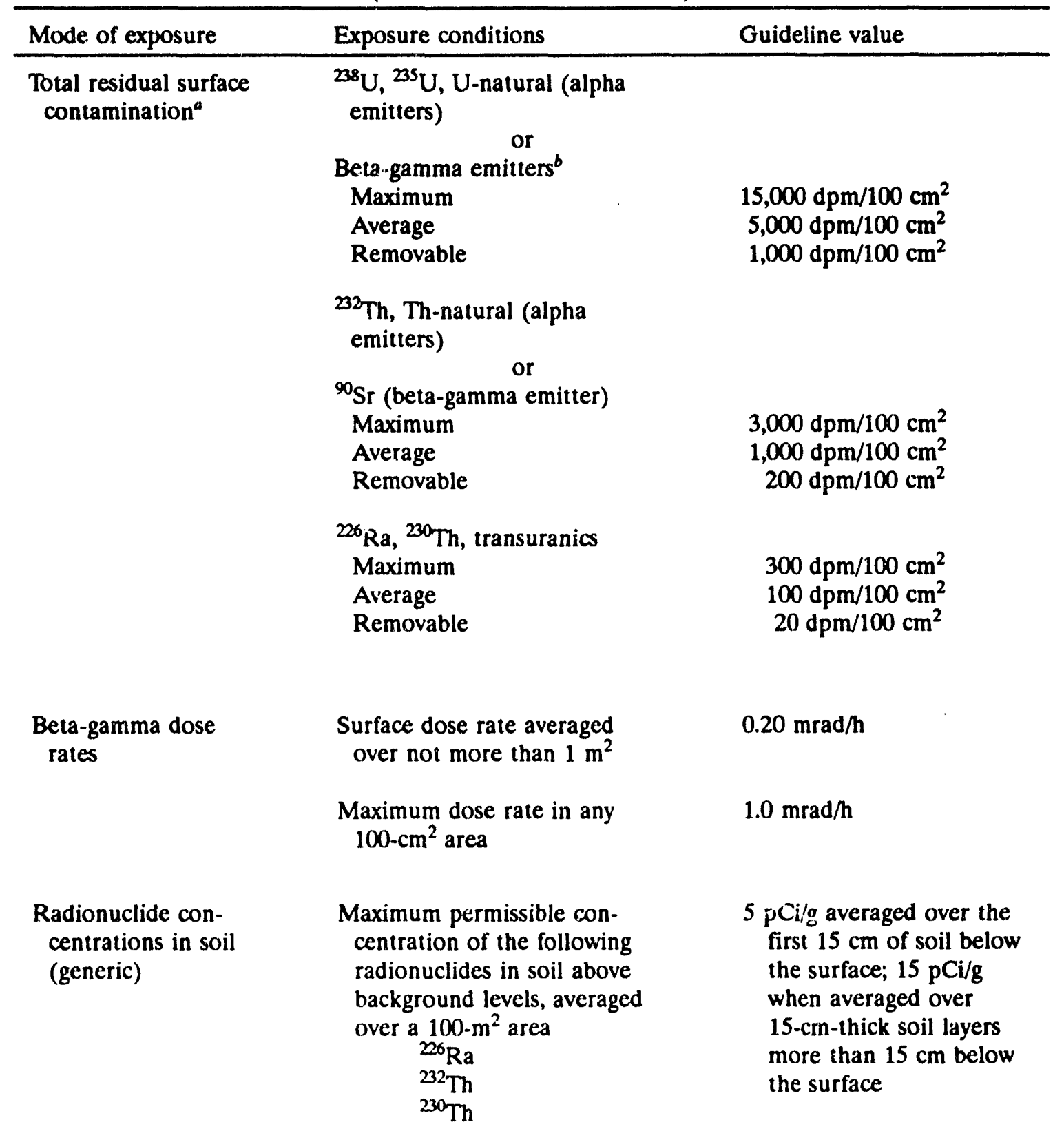


Table 1 (continued)

\begin{tabular}{lcc}
\hline Mode of Exposure & Exposure conditions & Guideline value \\
\hline Derived concentrations & ${ }^{238} \mathrm{U}$ & Site specific \\
& $\begin{array}{c}\text { Concentration limit in surface } \\
\text { soil above background levels } \\
\text { based on dose estimates from } \\
\text { major exposure pathways }\end{array}$ &
\end{tabular}

'DOE surface contamination guidelines are consistent with NRC Guidelines for Decontamination at Facilities and Equipment Prior to Release for Unrestricted Use or Termination of Licenses for By-Product, Source, or Special Nuclear Material, NUREG 1.86, May 1987.

bBeta-gamma emitters (radionuclides with decay modes other than alpha emission or spontaneous fission) except ${ }^{90} \mathrm{Sr},{ }^{228} \mathrm{Ra},{ }^{223} \mathrm{Ra},{ }^{227} \mathrm{Ac},{ }^{133} \mathrm{I},{ }^{129} \mathrm{I},{ }^{126} \mathrm{I},{ }^{125} \mathrm{I}$.

${ }^{\circ} \mathrm{DOE}$ guidelines for uranium are derived on a site-specific basis. Guidelines of $35-40 \mathrm{pCi} / \mathrm{g}$ have been applied at other FUSRAP sites. Source: J. L. Marley and R. F. Carrier, Results of the Radiological Survey at 4 Elmhurst Avenue, Colonie, New York (AL219), ORNL/RASA-87/117, Martin Marietta Energy Systems, Inc., Oak Ridge Natl. Lab., February 1988; B. A. Berven et al., Radiological Survey of the Former Kellex Research Facility, Jersey City, New Jersey, DOE/EV0005/29, ORNL-5734, Martin Marietta Energy Systems, Inc., Oak Ridge Natl. Lab., February 1982.

Sources: Adapted from U.S. Department of Energy, Radiological Control Manual, DOE/EH0256T (DOE N 5480.6), June 1992, U.S. Department of Energy, DOE Order 5400.5, April 1990, and U.S. Department of Energy, Guidelines for Residual Radioactive Material at Formerly Utilized Sites Remedial Action Program and Remote Surplus Facilities Management Program Sites, Rev. 2, March 1987.

Table 2. Background radiation levels for the northern New Jersey area

\begin{tabular}{cc}
\hline $\begin{array}{c}\text { Type of radiation measurement } \\
\text { or sample }\end{array}$ & $\begin{array}{c}\text { Radiation level or } \\
\text { radionuclide concentration }\end{array}$ \\
\hline $\begin{array}{c}\text { Gamma exposure at } 1 \mathrm{~m} \text { above } \\
\text { ground surface }(\mu \mathrm{R} / \mathrm{h})\end{array}$ & $8^{\mathrm{b}}$ \\
& \\
Concentration of radionuclides & \\
in soil $(\mathrm{pCi} / \mathrm{g})$ & $0.9^{\mathrm{c}}$ \\
$226 \mathrm{Ra}$ & $0.9^{\mathrm{c}}$ \\
$232 \mathrm{Th}$ & $0.9^{\mathrm{c}}$ \\
$238 \mathrm{U}$ & \\
\hline
\end{tabular}

These values represent an average of normal radionuclide concentrations in this part of the state. Actual values may fluctuate.

'Reference 4.

${ }^{'}$ Reference 5 . 
Table 3. Concentrations of radionuclides in soil at 77 Sinninger Street, Maywood, New Jersey (MJ052)

\begin{tabular}{lcccc}
\hline Sample & $\begin{array}{c}\text { Depth } \\
\text { (cm) }\end{array}$ & ${ }^{226 \mathrm{Ra}^{\mathrm{b}}}$ & ${ }^{232} \mathrm{Th}^{\mathrm{b}}$ & ${ }^{238} \mathrm{U}^{\mathrm{c}}$ \\
\cline { 3 - 4 } & \multicolumn{4}{c}{ Systematic samples ${ }^{\mathrm{d}}$} \\
S1A & $0-15$ & $0.83 \pm 0.07$ & $1.00 \pm 0.12$ & $2.3 \pm 0.35$ \\
S1B & $15-30$ & $0.94 \pm 0.07$ & $0.97 \pm 0.11$ & $1.2 \pm 0.27$ \\
& & & \\
S2A & $0-15$ & $0.91 \pm 0.02$ & $0.91 \pm 0.03$ & $1.4 \pm 0.6$ \\
S2B & $15-30$ & $0.86 \pm 0.11$ & $0.94 \pm 0.14$ & $1.1 \pm 0.47$ \\
S3A & $0-15$ & $0.93 \pm 0.10$ & $0.96 \pm 0.15$ & $2.2 \pm 0.50$ \\
S3B & $15-30$ & $0.75 \pm 0.07$ & $1.04 \pm 0.13$ & $1.3 \pm 0.29$ \\
S4A & $0-15$ & $0.87 \pm 0.02$ & $0.88 \pm 0.04$ & $1.7 \pm 0.55$ \\
S4B & $15-30$ & $0.72 \pm 0.06$ & $0.88 \pm 0.09$ & $1.2 \pm 0.41$ \\
\hline
\end{tabular}


ORNL/RASA-93/3

\section{INTERNAL DISTR.IBUTION}

1. B. A. Berven

2-6. K. J. Brown

7. R. F. Carrier

8. W. D. Cottrell

9-14. R. D. Foley

15. C. A. Johnson

16. M. E. Murray

17. P. T. Owen

18. D. A. Roberts

19. R. E. Rodriguez
20. P. S. Rohwer

21. R. E. Swaja

22. M. S. Uziel

23. J. K. Williams

24-25. Laboratory Records

26. Laboratory Records - RC

27. Central Research Library

28. ORNL Technical Lib., Y-12

29. ORNL Patent Section

30-35. MAD Records Center

\section{EXTERNAL DISTRIBUTION}

36. J. D. Berger, Oak Ridge Associated Universities, E/SH Division, Environmental Survey and Site Assessment Program, P.O. Box 117, Oak Ridge, TN 37831-0117

37. P. Doolittle, Booz-Allen \& Hamilton, Inc., 4330 East-West Highway, Bethesda, MD 20814

38. James J. Fiore, Director, Office of Eastern Area Programs, Office of Environmental Restoration, U.S. Department of Energy, (EM-42), Trevion II, Washington, DC 20585

39-41. G. K. Hovey, Bechtel National, Inc., FUSRAP Department, Oak Ridge Corporate Center, 151 Lafayette Drive, P.O. Box 350, Oak Ridge, TN 37831-0350

42-44. Jerry King, Science Applications International Corp., P.O. Box 2501, 301 Laboratory Road, Oak Ridge, TN 37831

45. L. K. Price, Director, Former Sites Restoration Division, Oak Ridge Operations, U.S. Department of Energy, P.O. Box 2001, Oak Ridge, TN 37831-8723

46. James W. Wagoner II, Director, Division of Off-Site Programs, Office of Eastern Area Programs, Office of Environmental Restoration, U.S. Department of Energy, (EM-421), Trevion II, Washington, DC 20585

47-51. W. Alexander Williams, Designation and Certification Manager, Division of Off-Site Programs, Office of Eastern Area Programs, Office of Environmental Restoration, U.S. Department of Energy, (EM-421), Trevion II, Washington, DC 20585

52-53. Office of Scientific and Technical Information, U.S. Department of Energy, P.O. Box 62, Oak Ridge, TN 37831

54. Office of Assistant Manager, Energy Research and Development, U.S. Department of Energy, DOE Field Office, Oak Ridge, TN 37831 

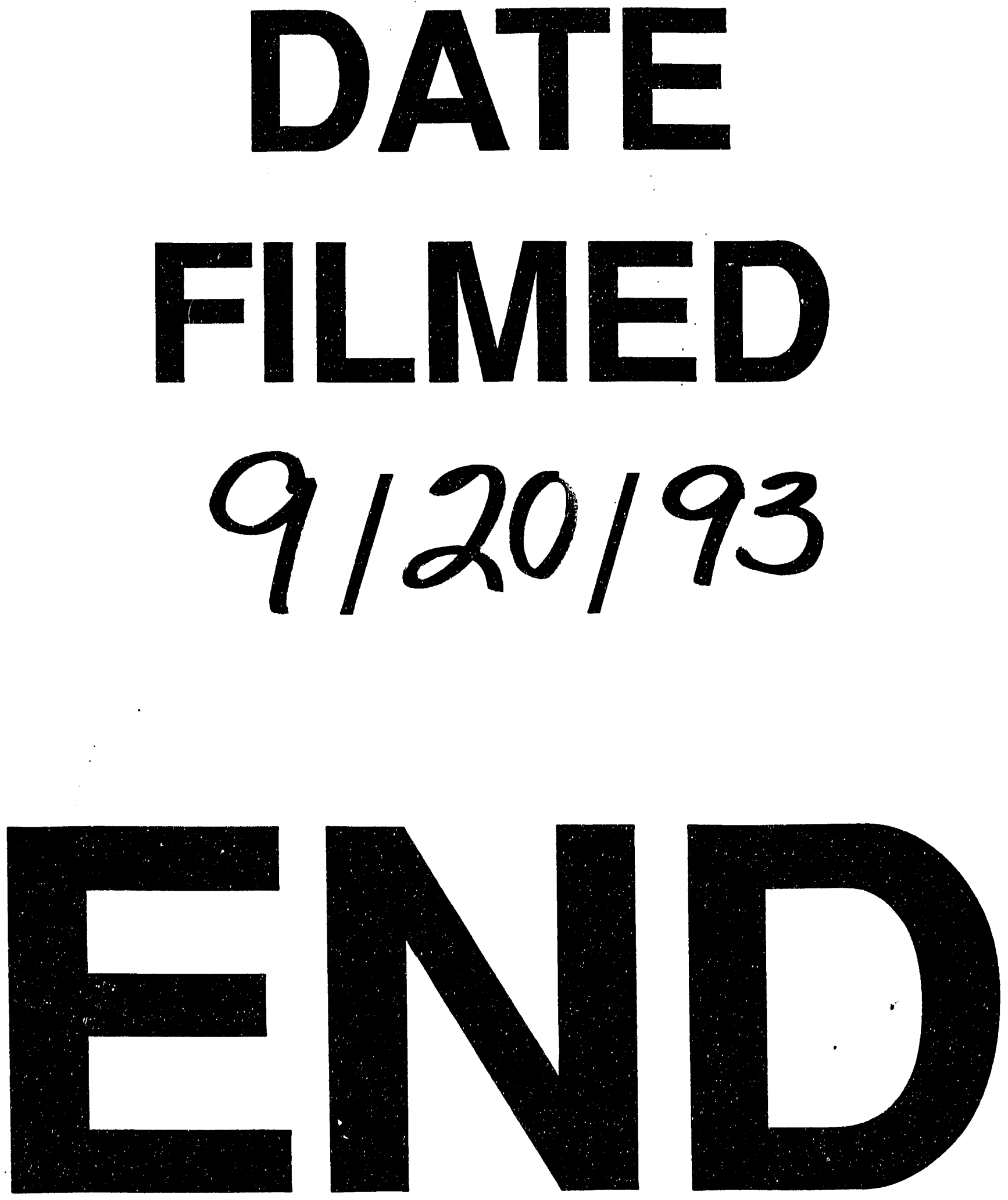
